\title{
Evaluation of Six Patients with Pulmonary Carcinosarcoma with a Literature Review
}

\author{
Sinem Nedime Sökücü,, ${ }^{1}$ Celalettin Kocatürk, ${ }^{2}$ Nur Ürer, ${ }^{3}$ Yaşar Sönmezoğlu, ${ }^{2}$ Levent Dalar, ${ }^{1}$ \\ Levent Karasulu, ${ }^{1}$ Sedat Altın, ${ }^{1}$ and Mehmet Ali Bedirhan ${ }^{2}$
}

${ }^{1}$ Department of Pulmonology, Yedikule Chest Disease and Thoracic Surgery Training and Research Hospital, Zeytinburnu, 34760 Istanbul, Turkey

${ }^{2}$ Department of Thoracic Surgery, Yedikule Chest Disease and Thoracic Surgery Training and Research Hospital, Zeytinburnu, 34760 İstanbul, Turkey

${ }^{3}$ Department of Pathology, Yedikule Chest Disease and Thoracic Surgery Training and Research Hospital, Zeytinburnu, 34760 Istanbul, Turkey

Correspondence should be addressed to Sinem Nedime Sökücü, sinemtimur@yahoo.com

Received 11 October 2011; Accepted 2 January 2012

Academic Editors: E. Briasoulis, B. L. Lum, A. Paulino, and G. Storme

Copyright ( 2012 Sinem Nedime Sökücü et al. This is an open access article distributed under the Creative Commons Attribution License, which permits unrestricted use, distribution, and reproduction in any medium, provided the original work is properly cited.

Background. Carcinosarcoma of the lung is a rare malignant neoplasm. We evaluated the diagnosis and treatment of six carcinosarcoma cases, including a synchronous tumour and a solitary pulmonary tumour, along with the clinical and histological features and survival times. Methods. From a retrospective analysis of 1076 non-small-cell lung cancer resections performed between January 1996 and January 2011, six patients (0.5\%) with pulmonary carcinosarcoma (all males; mean age 58 years; range 53-66) who underwent surgical treatment were studied. Results. The mean tumour pathological T diameter was $7.2 \mathrm{~cm}$ (median $6 \mathrm{~cm}$, range 3-14.5 cm). Only one patient was diagnosed with carcinosarcoma preoperatively. The clinical presentation and tumour localisations differed. The operations performed were a lobectomy $(n=4)$, pneumonectomy $(n=1)$, and bilobectomy $(n=1)$. Histologically, the epithelial characteristics of the tumours were consistent with squamous cell carcinoma in most of the patients. A complete resection was performed in all six patients. No mortality occurred in the early postoperative period. The median survival time was 9 (3-25) months. Conclusion. The preoperative diagnosis of carcinosarcoma of the lung is difficult due to the composition of the different histopathological structures. Complete surgical resection is the treatment of choice for pulmonary carcinosarcoma, although further studies are needed.

\section{Introduction}

Pulmonary carcinosarcoma (PCS) is a rare tumour in humans $[1,2]$. It was first defined by Kika et al. in 1908 as a poorly differentiated non-small-cell carcinoma containing a component with sarcoma or sarcoma-like features [3]. It accounts for 0.3 to $1 \%$ of all pulmonary cancers, and its clinical characteristics, preoperative diagnostic methods, and prognostic factors are still not completely understood [4]. Pulmonary carcinosarcomas occur predominantly in elderly men and middle-aged smokers [5]. This study evaluated the results of six cases who underwent surgery for PCS.

\section{Material and Method}

This was a retrospective study of six patients who underwent surgery for pulmonary tumours in our chest surgery clinic between January 1996 and January 2011 and who had a postoperative diagnosis of PCS. The patients were evaluated in terms of their age, gender, symptoms, diagnostic approaches, surgical methods, and followup findings.

All of the patients underwent routine laboratory studies, respiratory function tests, electrocardiography, chest X-ray, computed tomography (CT) of the thorax, brain CT or magnetic resonance imaging (MRI), abdominal ultrasound, 
TABLE 1: Characteristics of the patients.

\begin{tabular}{|c|c|c|c|c|c|c|c|}
\hline Patient & Age & $\begin{array}{c}\text { Cigar (pack } \\
\text { years) }\end{array}$ & Symptoms & $\begin{array}{l}\text { Endobronchial } \\
\text { Component }\end{array}$ & Localization & $\begin{array}{l}\text { Diameter }(\mathrm{cm}) \\
\text { CT/surgical }\end{array}$ & $\begin{array}{l}\text { Preoperative } \\
\text { diagnosis }\end{array}$ \\
\hline 1 & 63 & 90 & $\begin{array}{l}\text { Cough } \\
\text { hemoptysis }\end{array}$ & Yes & Right lower lobe & $3 / 3$ & $\begin{array}{l}\text { NSCLC } \\
\text { (epidermoid) }\end{array}$ \\
\hline 2 & 66 & 40 & $\begin{array}{l}\text { Chest pain, } \\
\text { Hemoptysis } \\
\text { Cough }\end{array}$ & Yes & Right central & $8 / 10$ & $\begin{array}{l}\text { NSCLC with } \\
\text { neuroendocrine } \\
\text { differantiation }\end{array}$ \\
\hline 3 & 54 & 60 & $\begin{array}{l}\text { Hemoptysis } \\
\text { Chest pain } \\
\text { Cough }\end{array}$ & No & $\begin{array}{l}\text { Right hiler } \\
\text { intermediate } \\
\text { Bronch }\end{array}$ & $5 / 6,5$ & Carcinosarcoma \\
\hline 4 & 53 & 50 & $\begin{array}{l}\text { Hemoptysis } \\
\text { Chest pain } \\
\text { Cough }\end{array}$ & No & Left lower lobe & $10 / 14,5$ & NSCLC \\
\hline 5 & 55 & 30 & - & No & Left upper lobe & $3 / 3,7$ & None \\
\hline 6 & 56 & 40 & $\begin{array}{l}\text { Chest pain } \\
\text { Dyspnea }\end{array}$ & No & Left lower lobe & $3,7 / 5,5$ & NSCLC \\
\hline
\end{tabular}

NSCLC: Non-small-cell lung carcinoma.

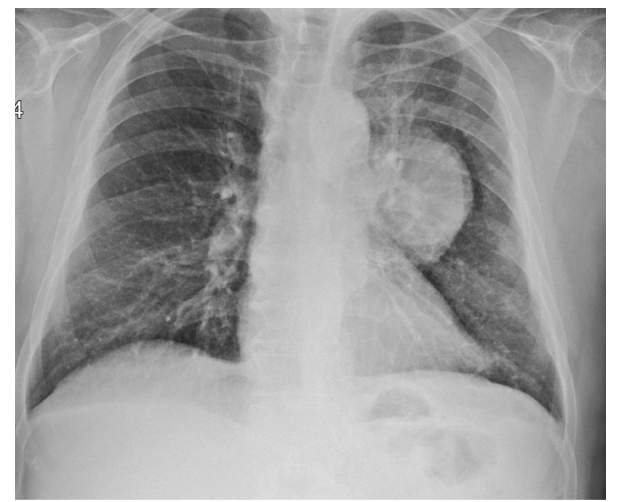

FIgURE 1: Chest X-ray of a patient showing a mass lesion located left hiler localization.

and bronchoscopy. Three patients underwent positron emission tomography (PET)-CT. In the preoperative period, one patient without a cancer diagnosis was suspected of having lung cancer, and one patient had a diagnosis of carcinosarcoma, whereas the other four patients were diagnosed with non-small-cell lung cancer (NSCLC). The patient who had a preoperative diagnosis of carcinosarcoma had an endobronchial component and was diagnosed by bronchoscopy. The mediastinal lymph nodes were evaluated by mediastinoscopy in all but one patient. A standard posterolateral thoracotomy incision and intraoperative staging were done in all patients. Complete resection was done in all patients. All of the tumours were staged postoperatively according to the seventh international TNM staging system. The diagnosis was verified immunohistochemically.

All patients underwent clinical and radiological followup for a median of 7.5 (range 3-25) months. All patients were assessed quarterly for the first 2 years with a history, physical examination, and chest X-ray. Laboratory tests and advanced radiological methods were requested if there were any symptoms. Additionally, all patients or the families were asked by phone when the study was performed and asked about any signs of recurrence or complications.

The statistical analysis was done using SPSS ver. 11.5. Descriptive analyses and Kaplan-Meier survival analysis were used.

\section{Results}

All six patients were male and heavy smokers (mean 52 packs/year (median 45, range 30-90)), with a median age of 56 (range 53-66) years. The most common presenting symptom was cough (Table 1 ).

Two of the tumours were located peripherally, three were located centrally (Figure 1), and the sixth had components in both areas. The diagnosis was made by fine-needle aspiration biopsy in two patients and by fibre optic bronchoscopy in three patients. Three of the six patients underwent PETCT. In these patients, pathological uptake was detected in the tumours, but no mediastinal involvement was detected. The operations performed were a pneumonectomy (due to 
TABle 2: Diagnostic characteristics of the lesions.

\begin{tabular}{|c|c|c|c|c|c|c|}
\hline Patient & TNM & Stage & $\begin{array}{l}\text { Cellular components } \\
\text { of end diagnosis }\end{array}$ & Resection & $\begin{array}{l}\text { Followup } \\
\text { time }(\mathrm{m})\end{array}$ & Prognosis \\
\hline 1 & T3N0M0 & IIB & $\begin{array}{l}\text { Squamous } \\
\text { Chondrosarcoma }\end{array}$ & $\begin{array}{l}\text { Right Lower } \\
\text { lobectomy }\end{array}$ & 10 & Death \\
\hline 2 & T3 N1M0 & IIIA & $\begin{array}{l}\text { Squamous } \\
\text { Osteosarcoma }\end{array}$ & $\begin{array}{l}\text { Right extrapleural } \\
\text { Pneumonectomy }\end{array}$ & 9 & Death \\
\hline 3 & T3N1M0 & IIIA & $\begin{array}{l}\text { Squamous } \\
\text { Spindle cell }\end{array}$ & $\begin{array}{l}\text { Right lower sleeve } \\
\text { bilobectomy }\end{array}$ & 25 & Alive \\
\hline 4 & T3N0M0 & IIB & $\begin{array}{l}\text { Adenocarcinoma } \\
\text { Osteosarcoma }\end{array}$ & $\begin{array}{l}\text { Left lower } \\
\text { lobectomy }\end{array}$ & 5 & Death \\
\hline 5 & T2ANOM0 & IB & $\begin{array}{l}\text { Adenocarcinoma } \\
\text { Chondrosarcoma }\end{array}$ & $\begin{array}{l}\text { Left upper } \\
\text { lobectomy }\end{array}$ & 6 & Alive \\
\hline 6 & T2BNOMO & IIA & $\begin{array}{l}\text { Squamous } \\
\text { Osteosarcoma }\end{array}$ & $\begin{array}{l}\text { Left lober } \\
\text { lowectomy }\end{array}$ & 3 & Death \\
\hline
\end{tabular}

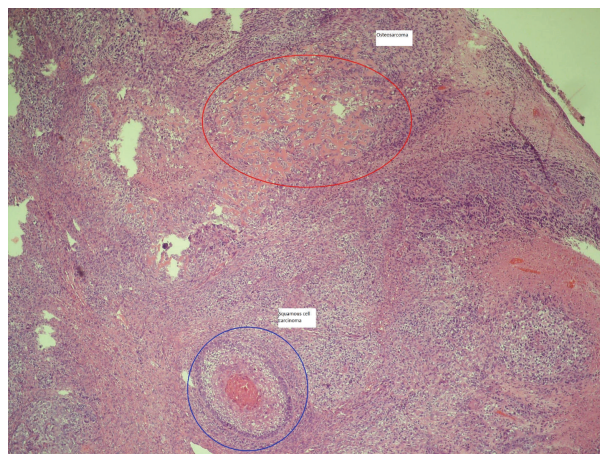

(a)

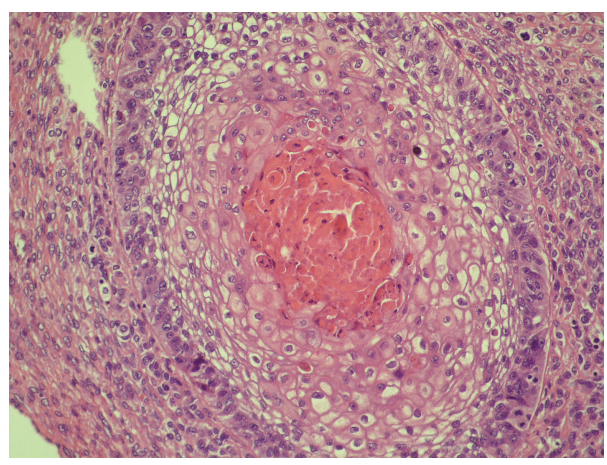

(b)

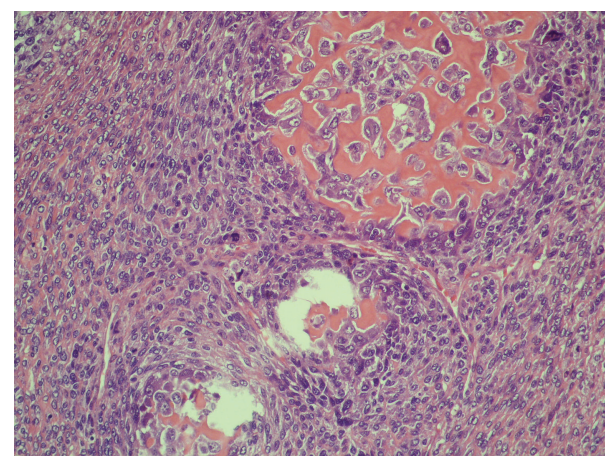

(c)

Figure 2: (a) Showing both squamous cell carcinoma and osteosarcoma seen in the same pies ( $\times 40 \mathrm{H} \& \mathrm{E})$. (b) With bigger magnification squamous cell carcinoma $(\times 400 \mathrm{H} \& \mathrm{E})$. (c) Osteosarcoma components from the same pies $(\times 400 \mathrm{H} \& \mathrm{E})$.

fissure invasion) in one patient, bilobectomy in another, and lobectomy in the others (Table 2).

Histologically, the epithelial characteristics of the tumours were consistent with squamous cell carcinoma $(n=4)$ and adenocarcinoma $(n=2)$. The sarcomatous component was mostly chondrosarcomatous type and osteosarcomatous type (Table 2, Figure 2). No mortality occurred in the early postoperative period, although a bronchopleural fistula (BPF) developed in two patients in the first postoperative month. A right lower bilobectomy was done in one of these patients, and the BPF was treated with a complementary pneumonectomy and omentoplasty. In the other patient, a right pneumonectomy was done to treat the tumour invasion of the fissure, and the BPF was treated with an omentoplasty.

All of the patients were sent for oncological evaluations, and two patients with $\mathrm{N} 1$ disease received chemotherapy; chemotherapy was not deemed necessary for the others. In 
one patient, a synchronous squamous cell carcinoma (stage IA) was also detected. This patient refused further treatment after one dose of chemotherapy.

One of the patients died from brain metastasis at 10 months, and three other patients died of local metastases at 3,5 , and 9 months, respectively. Only two of the six patients were alive at the time of evaluation. The median survival time was 9 months (95\% CI 1,16-16,84; range 3-25).

\section{Discussion}

Pulmonary carcinosarcoma is a subgroup of pulmonary sarcomatoid carcinomas. Currently, pulmonary sarcomatoid carcinomas are defined as poorly differentiated non-smallcell carcinomas containing a component with sarcoma or sarcoma-like (spindle or giant cell) features. Its definition was ambiguous until the recent establishment of World Health Organisation (WHO) criteria, which classify it into carcinosarcoma, pleomorphic carcinoma, and spindle cell carcinoma [6].

Pulmonary carcinosarcoma is more common among males with a smoking history. The literature reports a 4to 7.25-fold male dominance [7-9]. In our group, all of the patients were male, with a mean age of 58 years, and all were heavy cigarette smokers, as expected.

The gross pathology of the tumour was either an intraparenchymal or intrabronchial polypoid mass. Koss et al. reported central localisation in $62 \%$ of cases [5]. The clinical presentation of the centrally localised type involves a cough, dyspnoea, and haemoptysis, like other endobronchial tumours. The second type of PCS, the peripheral solid parenchymal type, often presents as a large mass. These tumours are asymptomatic in the early stage, during which time they may involve the adjacent organs or structures such as the mediastinum, pleura, and thoracic wall [10]. Moore reported that one-third of these tumours were located peripherally [11], whereas Yazıcı et al. reported a peripheral location in $85.7 \%$ [12]. In our series, $66 \%$ of the patients had peripheral tumours, and their symptoms were consistent with the literature. Interestingly, one presented with a solitary pulmonary nodule. Although the reported radiological properties of these tumours in the English literature do not include solitary pulmonary nodule, this can also be a presentation of PCS.

In three of the six patients, PET-CT was performed. Two patients had positive uptake, and the other case was borderline. Only one paper about mean positron emission tomography uptake was published in the English language literature and it found that uptake of sarcomatoid carcinoma is significantly higher than in other types of lung cancer $(P<$ $0.0001)$ [13]. No other information on the PET-CT findings of PCS of the lung has been reported, and the findings in our series were variable.

In our cases, the mean tumour diameter was $7.2 \mathrm{~cm}$, which concurs with the literature. Our series had lowerlobe dominance in contrast to the reported upper-lobe dominance $[5,10,11]$.

Immunohistochemical techniques are used to differentiate the epithelial and mesenchymal tumour elements of carcinosarcomas. The carcinomatous component is nonsmall-cell lung carcinoma, including squamous cell carcinoma, adenocarcinoma, and large-cell carcinoma. The most common epithelial component is squamous cell carcinoma. Takeda et al. reported a rate of $69 \%$ for squamous cell carcinoma, 24\% for adenocarcinoma, and 6\% for a combination of carcinomas [8]. Koss et al. reported that the most frequent epithelial component was squamous cell carcinoma (46\%), followed by adenocarcinomas (31\%) and adenosquamous cell carcinoma (19\%) [5]. Similarly, in $67 \%$ of our cases, the epithelioid component was squamous cell carcinoma, and it was adenocarcinoma in $33 \%$. The sarcomatous component involves poorly differentiated osteosarcoma, chondrosarcoma, or rhabdomyosarcoma [5, $7,8]$. In our cases, osteosarcoma, chondrosarcoma, and spindle cell carcinoma were mostly seen in the sarcomatous component.

Interestingly, one of our cases had a synchronous tumour at the time of diagnosis. The pathological diagnosis of one of these two tumours was carcinosarcoma, whereas the other one was a stage Ia (T1N0M0) squamous cell carcinoma located in the other lobe, without involvement of the shared lymph nodes. Synchronous tumours are rare [14], and synchronous tumours in which one component is carcinosarcoma are rarer, with no other case reported in the English-language literature.

Complete surgical removal of the tumour with negative tumour margins constitutes the desired treatment approach. There is limited information on systemic treatment options such as chemotherapy and radiotherapy $[15,16]$. Nevertheless, the aggressive nature and poor differentiation of this tumour render the treatment difficult and result in a poor prognosis [17]. Although relatively satisfying survival rates have been reported in some series $(49.3 \%$ by Petrov et al. and $57 \%$ by Yazici et al.), the survival was poor in others $(21.3 \%$ in Koss et al.) $[5,12,18]$. In a most recent series involving sarcomatoid carcinoma reported by Park et al., survival rates have been reported as $54.3 \%$ and mean followup was 16.07 months [13]. In our series, the median survival time was 9 months.

Although complete resection was performed on all of our tumours, the survival time was short, as in Koss et al. [5]. Fishback et al. reported that a tumour diameter larger than $5 \mathrm{~cm}$, disease stage higher than stage I, and the presence of lymph node involvement had negative effects on the prognosis $[4,19]$.

In most cases, the preoperative diagnosis is incomplete, and lung resection is needed for a definite diagnosis. The complete, correct diagnosis in five of our six cases could not be made before resection. Although local metastases after complete surgical resection are rare in NSCLC, we recorded local metastases in two of the PCS cases. We explained this as due to the aggressive local behaviour of the tumour, as did Sato et al. [20].

Metastasis is frequent and is most common to the lymph nodes, followed by the kidneys, bones, liver, and brain [5]. One of our cases died of brain metastasis at 10 months.

In conclusion, a preoperative diagnosis of carcinosarcoma of the lung is difficult due to the composition of 
the different histopathological structures. This tumour can present as a solitary pulmonary nodule or as a component of synchronous tumours. Unlike reports in the literature, it can also involve the lower lobe. Complete surgical resection is still the only effective treatment for pulmonary carcinosarcoma, but the prognosis is poor. The clinical and prognostic properties of carcinosarcomas are still unknown, and more studies and larger multicentric series are needed.

\section{Acknowledgments}

The English in this document has been checked by at least two professional editors, both native speakers of English. For a certificate, please see http://www.textcheck.com/certificate/7NoFJ0.

\section{References}

[1] M. P. Davis, R. T. Eagan, L. H. Weiland, and P. C. Pairolero, "Carcinosarcoma of the lung: mayo clinic experience and response to chemotherapy," Mayo Clinic Proceedings, vol. 59, no. 9, pp. 598-603, 1984.

[2] H. Huwer, G. Kalweit, U. Straub, P. Feindt, I. Volkmer, and E. Gams, "Pulmonary carcinosarcoma: diagnostic problems and determinants of the prognosis," European Journal of CardioThoracic Surgery, vol. 10, no. 6, pp. 403-407, 1996.

[3] G. S. Kakos, T. E. Williams Jr., D. Assor, and J. S. Vasko, "Pulmonary carcinosarcoma. Etiologic, therapeutic, and prognostic considerations," Journal of Thoracic and Cardiovascular Surgery, vol. 61, no. 5, pp. 777-783, 1971.

[4] N. F. Fishback, W. D. Travis, C. A. Moran, D. G. Guinee Jr., W. F. McCarthy, and M. N. Koss, "Pleomorphic (spindle/giant cell) carcinoma of the lung: a clinicopathologic correlation of 78 cases," Cancer, vol. 73, no. 12, pp. 2936-2945, 1994.

[5] M. N. Koss, L. Hochholzer, and R. A. Frommelt, "Carcinosarcomas of the lung: a clinicopathologic study of 66 patients," American Journal of Surgical Pathology, vol. 23, no. 12, pp. 1514-1526, 1999.

[6] G. Pelosi, A. Sonzogni, T. de Pas et al., "Review article: pulmonary sarcomatoid carcinomas: a practical overview," International Journal of Surgical Pathology, vol. 18, no. 2, pp. 103$120,2010$.

[7] M. Nakajima, T. Kasai, H. Hashimoto, Y. Iwata, and H. Manabe, "Sarcomatoid carcinoma of the lung: a clinicopathologic study of 37 cases," Cancer, vol. 86, no. 4, pp. 608-616, 1999.

[8] S. I. Takeda, S. Nanjo, K. Nakamoto, T. Imachi, and S. Yamamoto, "Carcinosarcoma of the lung: report of a case and review of the literature," Respiration, vol. 61, no. 2, pp. 113116, 1994.

[9] D. Cohen-Salmon, R. P. Michel, N. S. Wang, D. Eddy, and R. Hanson, "Pulmonary carcinosarcoma and carcinoma: report of a case studied by electron microscopy, with critical review of the literature," Annales de Pathologie, vol. 5, no. 2, pp. 115124, 1985.

[10] P. A. Humphrey, M. W. Scroggs, V. L. Roggli, and J. D. Shelburne, "Pulmonary carcinomas with a sarcomatoid element: an immunnocytochemical and ultrastructural analysis," Human Pathology, vol. 19, no. 2, pp. 155-165, 1988.

[11] T. C. Moore, "Carcinosarcoma of the lung," Surgery, vol. 50, no. 6, pp. 886-893, 1961.
[12] Ü Yazıc1, İ Taştepe, E Gülhan et al., "Pulmonary carcinosarcomas: en evaluation of seven patients," Türk Göğüs Kalp Damar Cerrahisi Dergisi, vol. 17, no. 1, pp. 036-039, 2009.

[13] J. S. Park, Y. Lee, J. Han et al., "Clinicopathologic outcomes of curative resection for sarcomatoid carcinoma of the lung," Oncology, vol. 81, no. 3-4, pp. 206-213, 2011.

[14] C. I. Kocaturk, M. Z. Gunluoglu, L. Cansever et al., "Survival and prognostic factors in surgically resected synchronous multiple primary lung cancers," European Journal of CardioThoracic Surgery, vol. 39, no. 2, pp. 160-166, 2011.

[15] T. Sugano, M. Mori, Y. Namba, T. Uenami, S. Kagami, and S. Yokota, "A case of sarcomatoid carcinoma of the lung successfully treated with carboplatin, paclitaxel and bevacizumab," Nihon Kokyūki Gakkai zasshi, vol. 49, no. 4, pp. 304-308, 2011 (Japanese).

[16] F. Langer, H. O. Wintzer, M. Werner, C. Weber, T. H. Brümmendorf, and C. Bokemeyer, "A case of pulmonary carcinosarcoma (squamous cell carcinoma and osteosarcoma) treated with cisplatin and doxorubicin," Anticancer Research, vol. 26, no. 5 B, pp. 3893-3897, 2006.

[17] G. Pelosi, A. Sonzogni, T. de Pas et al., "Pulmonary sarcomatoid carcinomas: a practical overview," International Journal of Surgical Pathology, vol. 18, no. 2, pp. 103-120, 2010.

[18] D. B. Petrov, V. I. Vlassov, G. T. Kalaydjiev et al., "Primary pulmonary sarcomas and carcinosarcomas-postoperative results and comparative survival analysis," European Journal of Cardio-Thoracic Surgery, vol. 23, no. 4, pp. 461-466, 2003.

[19] T. Yuki, T. Sakuma, C. Ohbayashi et al., "Pleomorphic carcinoma of the lung: a surgical outcome," Journal of Thoracic and Cardiovascular Surgery, vol. 134, no. 2, pp. 399-404, 2007.

[20] S. Sato, T. Koike, Y. Yamato et al., "A case of rapidly growing pulmonary carcinosarcoma," International Journal of Clinical Oncology, vol. 15, no. 3, pp. 319-324, 2010. 


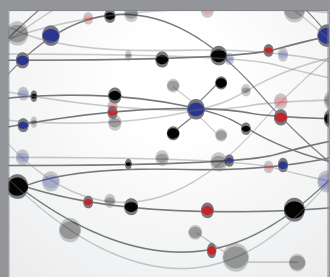

The Scientific World Journal
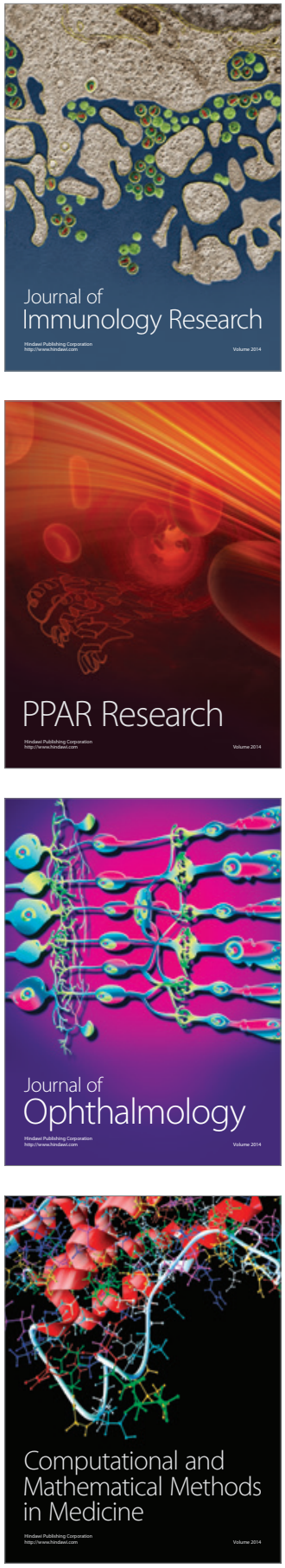

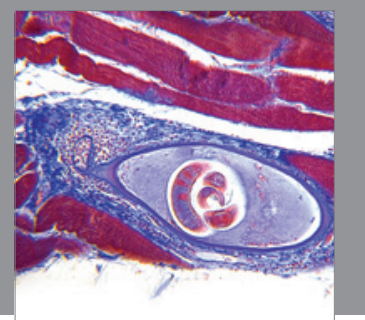

Gastroenterology

Research and Practice
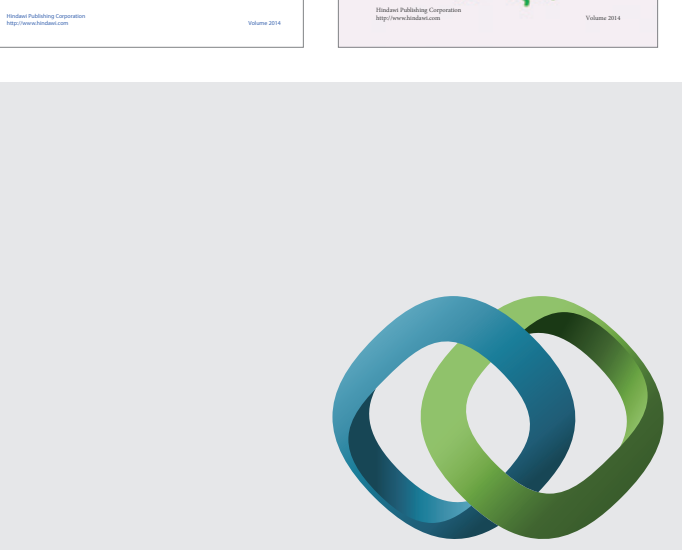

\section{Hindawi}

Submit your manuscripts at

http://www.hindawi.com
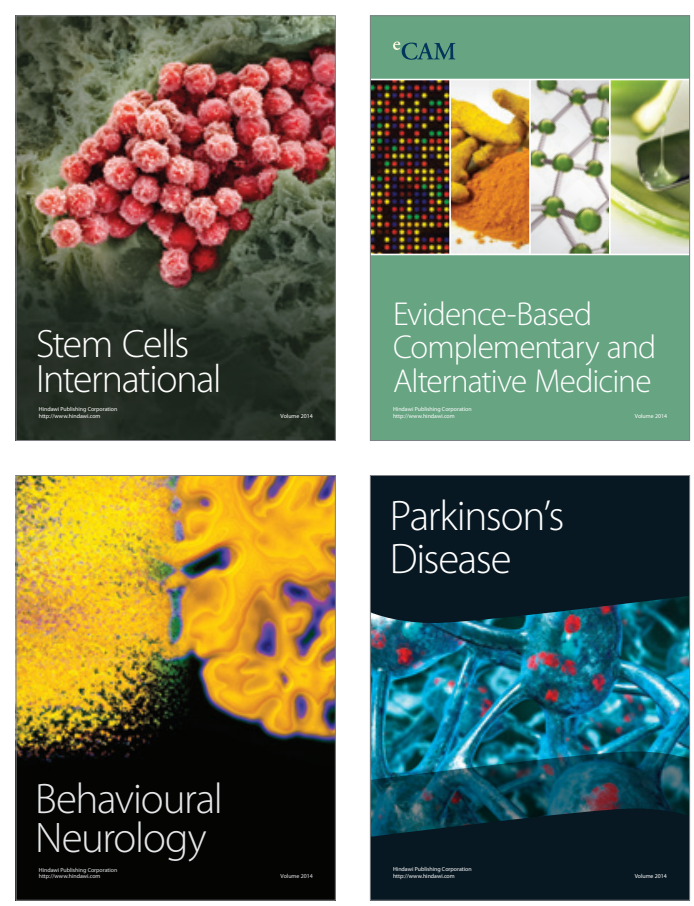

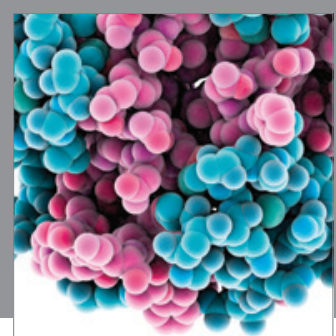

Journal of
Diabetes Research

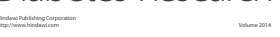

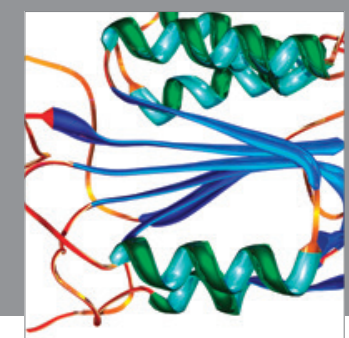

Disease Markers
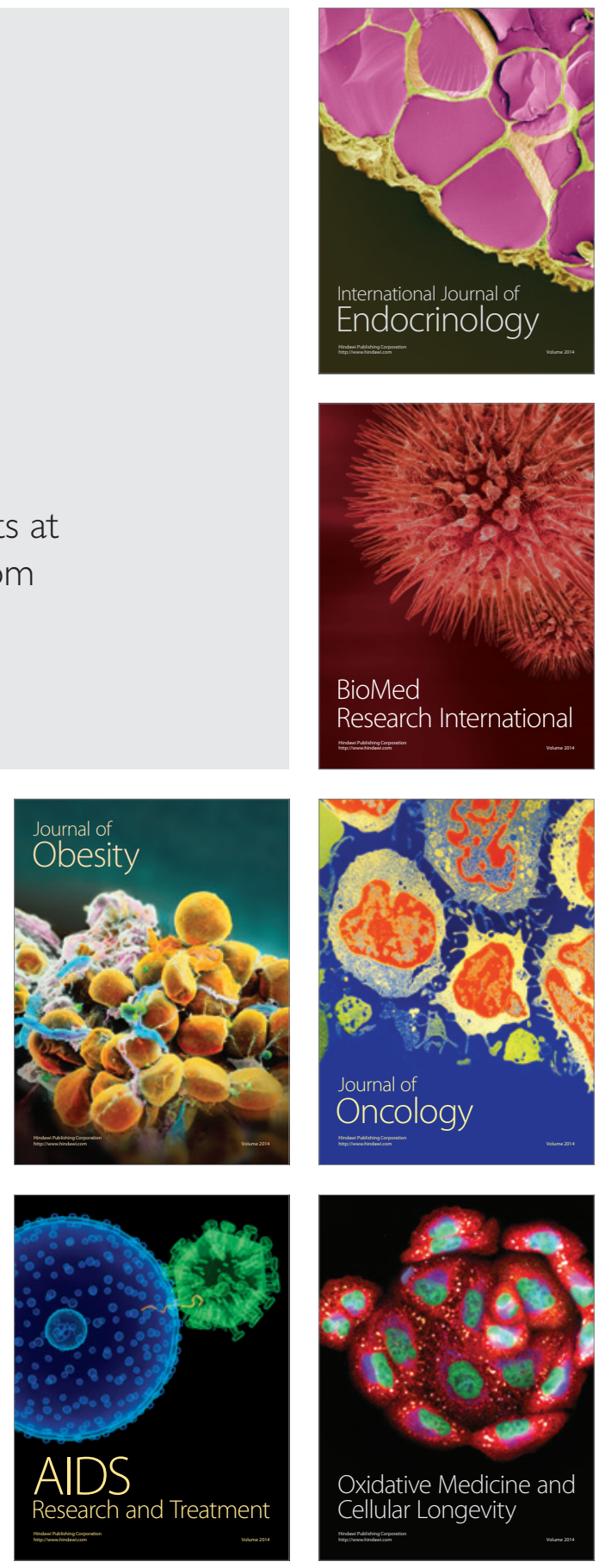